\title{
Impact of dermatologic adverse reactions on QOL in oncologic patients: results from a single-center prospective study
}

\author{
MARIA ALEXANDRA BARBU ${ }^{1,2}$, CORNELIA NIȚIPIR $^{1,2}$, THEODOR VOIOSU $^{1}$, CĂLIN GIURCĂNEANU $^{1,3}$ \\ 1"UMF Carol Davila" School of Medicine, Bucharest \\ ${ }^{2}$ Medical Oncology Department, Elias University Emergency Hospital, Bucharest \\ ${ }^{3}$ Dermatooncology Department, Elias University Emergency Hospital, Bucharest
}

\begin{abstract}
Introduction. Skin toxicity in patients receiving novel therapeutic cancer agents has become a very important marker in determining drug activity, but it can also severely impact their quality of life. About half of the patients receiving this type of oncologic treatment will develop cutaneous reactions, that is why adequate understanding and management of these side effects is very important for drug adherence and patients' quality of life.

Materials and methods. We conducted a prospective study of consecutive patients who received oncologic treatment in our institution and presented with dermatologic side effects. The severity of skin toxicity was assessed using the DLQI score and patients were prospectively followed to evaluate response to therapy. Univariate analysis of factors influencing the impact of skin toxicity on patient QOL was conducted.

Results. 52 patients were enrolled in the study. Patients who developed grade 3 and 4 skin toxicity had a higher DLQI score, with a greater impact on quality of life, but with better clinical outcome at 3 months follow-up, based on RECIST. Patients with moderate or severe cutaneous AE were more likely to achieve complete or partial response to therapy than those with mild AE (16/33 vs. $3 / 19, \mathrm{p}=0.035)$. Interestingly, female patients had a significantly poorer quality of life than male patients as assessed by the DLQI score $(7.28 \pm 7 v s .3 .7 \pm 3.6, \mathrm{p}=0.038)$.

Conclusion. Cutaneous side effects are often encountered in cancer patients and their severity can be a surrogate marker for a positive clinical tumor response to therapy.
\end{abstract}

Key words: exanthema, toxicity, EGFR tyrosine kinase inhibitor, quality of life, chemotherapy.

\section{INTRODUCTION}

The advent of new therapeutic agents and strategies in the field of oncology, most notably the development of personalized medicine, has resulted in a prolonged life and longer disease free survival for cancer patients. However, this new era of oncological medicine brought with it cutaneous reactions that arise as side effects from these therapies.

Skin conditions can result in a reduction or discontinuation of chemotherapy regimens and can have a severe impact on cancer patients' quality of life, with very important physical, psychological and financial implications [1].

Skin toxicity that is usually induced by classical chemotherapy can present as nail changes (paronychia, changes in pigmentation, onycholysis, mees lines), exfoliative dermatitis, hyperpigmentation, hand-foot syndrome (acral erythema, palmoplantar erythrodysesthesia), alopecia, photosensitivity and severe skin reactions like Stevens Johnson syndrome, Raynaud syndrome or ulcers [2].
Patients treated with novel targeted anticancer drugs, like epidermal growth factor receptor inhibitors (EGFRI) or mammalian target of rapamycin inhibitors or tyrosine kinase inhibitors can develop muco-cutaneous side effects such as acneiform-like rash, pruritus, paronychia, xerosis, exanthematous popular rash, hair changes, hand-foot syndrome, hypo/hyperpigmentation [2, 3].

For the diagnosis and management of these side effects, a multidisciplinary team approach is necessary, usually consisting of a medical oncologist and a dermatology specialist. A clinical staging of these side effects can help orient the physician to either reduce doses or discontinue cancer therapy altogether, with an important impact on clinical outcome. There are several grading systems currently in use: the National Cancer Institute's Common Criteria for Adverse Events (CTCAE) - most frequently used scale in clinical practice, DERETT Dermatologic Reaction Targeted Therapy - patient Symptom Experience Diary, the Functional Assessment of Cancer Therapy Epidermal Growth Factor Receptor Inhibitor 18 (FACT-EGFRI-18) scale, 
Skindex-16 and Hair Specific Skindex-29, the HandFoot Syndrome 14 (HFS-14), mTOR inhibitorassociated stomatitis scale (mIAS) [4].

Using these tools to grade the cutaneous adverse reactions in cancer patients helps the physician to objectively measure their impact on patients quality of life and, subsequently, to manage the doses and to reassess the therapeutic protocol for these patients.

The aim of our study is to measure the impact of cutaneous side effects on patients' quality of life and to verify if skin toxicity can represent an early marker of tumour shrinkage and if this can be associated with clinical benefit.

\section{MATERIALS AND METHODS}

\section{Study design}

We conducted a prospective study of all oncologic patients presenting with dermatologic adverse events in a tertiary cancer center. Baseline evaluation consisted of a dermatologic consultation including type of adverse events (hand-foot syndrome, erythema, hypo/hyperpigmentation, acneiform rash, paronychia, xerosis, hair changes), severity (according to CTCAE v4.0 scale [5]) and therapeutic intervention. All patients were asked to complete a validated quality of life questionnaire DLQI (Dermatology Quality of Life Index), consisting of 10 simple questions that assess the patient's perception regarding the impact of skin pathology on their feelings, daily activities, work, personal relationships in the last week. This questionnaire was developed in 1994 by Finlay AY and Khan GK based on the answers of one hundred and twenty persons with different skin toxicities who were asked about the impact of their disease in their lives [6]. Each question is scored from 0 (not at all or not relevant) to 3 (very high impact on daily activities), with higher scores meaning a greater impact on patients' quality of life. This questionnaire is the most frequently used in dermatologic trials all over the world; it has been validated for use in over 90 different languages, including Romanian, and is readily available online from the Cardiff University Department of Dermatology [7].

Clinical data regarding cancer type, staging and chemotherapy regimen as well as concomitant therapy for coexisting conditions was collected at baseline and reviewed at each subsequent study visit. Follow-up visits were scheduled every 3 months and all patients were followed for a minimum of 6 months after adverse event (AE) resolution or until death, whichever occurred first. Data regarding the evolution of the underlying disease and the impact of the dermatologic adverse event on the oncologic treatment was collected at each follow-up visit. Of note, none of the patients received prophylactic dermatologic treatment.

\section{Outcome measures}

The primary end-point of the study was the impact of chemotherapy on the quality of life (QOL) of oncologic patients, as assessed by the DLQI questionnaire. Disease progression at 6 months follow-up and the association between cutaneous $\mathrm{AE}$ severity and response to treatment were seconddary end points in the study.

\section{Statistical analysis}

Results are expressed as frequencies for categorical variables (further analyzed by Fisher's exact test), mean and standard deviation for normal continuous variables (analyzed by Student's t test), and median and extremes for non-normal continuous variables (analyzed by the Mann-Whitney $U$ and Kruskall Wallis tests). DLQI levels were compared across study groups, acording to gender and disease severity using the Mann Whitney U test. Hypothesis testing was 2-tailed, with $\mathrm{p}<0.05$ considered statistically significant. The statistical software package SPSS for Windows Version 16.0 (SPSS Inc., Chicago, IL) was used to analyze the data.

\section{RESULTS}

Fifty-two patients ( 25 female, mean age $56 \pm$ 11 years) presented with dermatologic adverse events (AE) to chemotherapy in our unit between October 2015 - October 2017. The majority of patients $(32 / 52)$ were diagnosed with stage IV cancer and all others had advanced disease using TNM classification staging system. Most patients (13/52) were undergoing chemotherapy for head and neck cancers, followed by lung cancer (9/52) and colorectal cancer (7/52), with cetuximab (an EGFR inhibitor) being used in 18 cases (34\%), followed by erlotinib (TK inhibitor) in $14(27 \%)$ and conventional chemotherapy in $12(23 \%)$ of cases. Baseline data is shown in detail in Table 1. 
Papulopustular rash (acneiform rash) was the most frequently noted $\mathrm{AE}(60 \%)$, followed by hand foot syndrome $(10 \%)$ and various other conditions (Table 2). Twenty eight patients (53\%) developed more than one type of cutaneous adverse reactions, in these cases the more severe toxicity was taken into consideration for further analysis. $36 \%$ of cases were graded as mild, $44 \%$ were graded as moderate and $20 \%$ were considered severe, according to Common Terminology Criteria for Adverse Events v4.0 score.

Table 1

Baseline data of the study group according to the severity of cutaneous adverse events

\begin{tabular}{|c|c|c|c|}
\hline & Mild AE & Moderate/Severe AE & p-value \\
\hline Gender (male/female) & $13 / 6$ & $14 / 19$ & 0.08 \\
\hline $\operatorname{Age}(\operatorname{mean} \pm \mathrm{SD})$ & 56.7 years $( \pm 12.3)$ & 56 years $( \pm 10.8)$ & 0.8 \\
\hline \multicolumn{4}{|l|}{ Cancer type (\%) } \\
\hline Head and neck & $5(26.4 \%)$ & $8(24.3 \%)$ & \multirow[t]{5}{*}{0.69} \\
\hline Lung cancer & $2(10.5 \%)$ & $7(21.2 \%)$ & \\
\hline Colorectal cancer & $3(15.7 \%)$ & $4(12.1 \%)$ & \\
\hline Pancreatic cancer & $3(15.7 \%)$ & $2(6 \%)$ & \\
\hline Other types & $6(31.6 \%)$ & $12(36.4 \%)$ & \\
\hline \multicolumn{3}{|l|}{ Drug regimen $(\%)$} & \multirow[t]{6}{*}{0.33} \\
\hline Cetuximab & $7(36.8 \%)$ & $11(33.3 \%)$ & \\
\hline Erlotinib & $5(26.4 \%)$ & $9(27.4 \%)$ & \\
\hline Sunitinib & $4(21 \%)$ & $2(6 \%)$ & \\
\hline Sorafenib & $1(5.3 \%)$ & $1(3 \%)$ & \\
\hline Conventional chemotherapy (taxanes) & $2(10.5 \%)$ & $10(30.3 \%)$ & \\
\hline
\end{tabular}

Table 2

Adverse cutaneous side effects

\begin{tabular}{|l|c|}
\hline Type of skin toxicity (\%) & \\
\hline Papulopustular rash & $31(59.6 \%)$ \\
\hline Hand foot syndrome & $5(9.6 \%)$ \\
\hline Hypertricosis & $5(9.6 \%)$ \\
\hline Paronychia & $4(7.7 \%)$ \\
\hline Splinter hemorrhages & $3(5.8 \%)$ \\
\hline Depigmentation & $1(1.9 \%)$ \\
\hline Xerosis & $1(1.9 \%)$ \\
\hline Ectropion & $1(1.9 \%)$ \\
\hline Other & $1(1.9 \%)$ \\
\hline Type of dermatological treatment (\%) & \\
\hline No treatment & $1(1.9 \%)$ \\
\hline Topical treatment & $39(75 \%)$ \\
\hline Systemic therapy (antibiotics) & $12(23.1 \%)$ \\
\hline
\end{tabular}

Most patients (39/52 - 75\%) received topical treatment using corticosteroid and vitamin $\mathrm{K} 1$ cream [8]. Twelve patients (23.1\%) required systemic therapy (antibiotics \pm corticosteroids) and 1 patient received no additional dermatological treatment. Most patients presenting with mild AE (89.4\%) did not delay or discontinue oncologic medication, while 20/33 (60.6\%) patients presenting with moderate or severe $\mathrm{AE}$ had to discontinue treatment for 1 to 2 weeks ( $p<0.001$ Fisher's exact test).

Patients who developed either moderate or severe cutaneous AE were more likely to achieve complete or partial response to therapy at 3 months than those who only developed mild AE $(48.5 \%$ vs. $15.7 \%, p=0.035$ Fisher's exact test). At 6 months follow-up, 12 out of 33 patients (36.3\%) with moderate or severe AE still had complete or partial response to therapy compared to just $3 / 19(15.7 \%)$ with mild cutaneous $\mathrm{AE}$ at baseline; however the difference was no longer statistically significant $(p=0.2$ Fisher's exact test).

DLQI scores were associated with AE severity, with more severe disease resulting in lower QOL scores (Fig. 1), with median DQLI of 2 (range 0-19), 5 (range 0-24) and 5.5 (range 2-24) for mild, moderate and severe manifestations respectively ( $\mathrm{p}=0.012$, Kruskall-Wallis). Female patients showed more severe QOL impairment as a result of cutaneous $\mathrm{AE}$, with significantly higher median DLQI compared to male patients at univariate analysis 5 , range $0-24$ vs. 2 , range $0-13 \mathrm{p}=0.038$ Mann Whitney U) (Fig. 2). 
There was no significant difference in the severity of cutaneous toxicity or QOL impairment according to the type of cancer treatment. Patients receiving targeted therapy had similar median DLQI scores compared with those on taxan-based conventional chemotherapy regimens ( 3 , range $0-24 v s$. 5, range $0-24, p=0.11$ Mann Whitney U) and a similar rate of moderate/severe adverse events $(57.5 \%$ vs. $83.3 \%, \mathrm{p}=0.17$ Fisher's exact test).

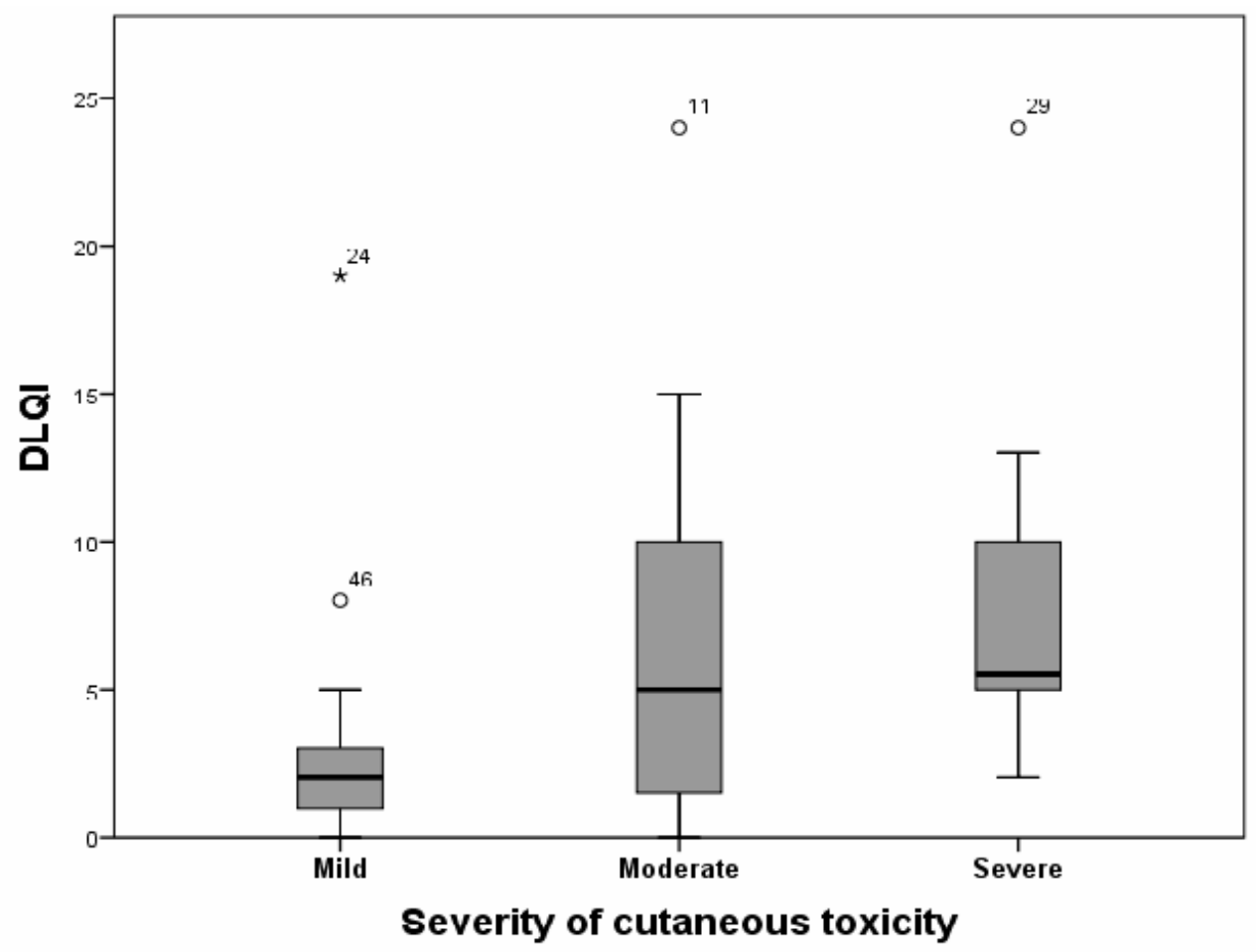

Figure 1. Comparison of DLQI scores according to the severity of cutaneous toxicity ( $p=0.012$ Kruskall Wallis).

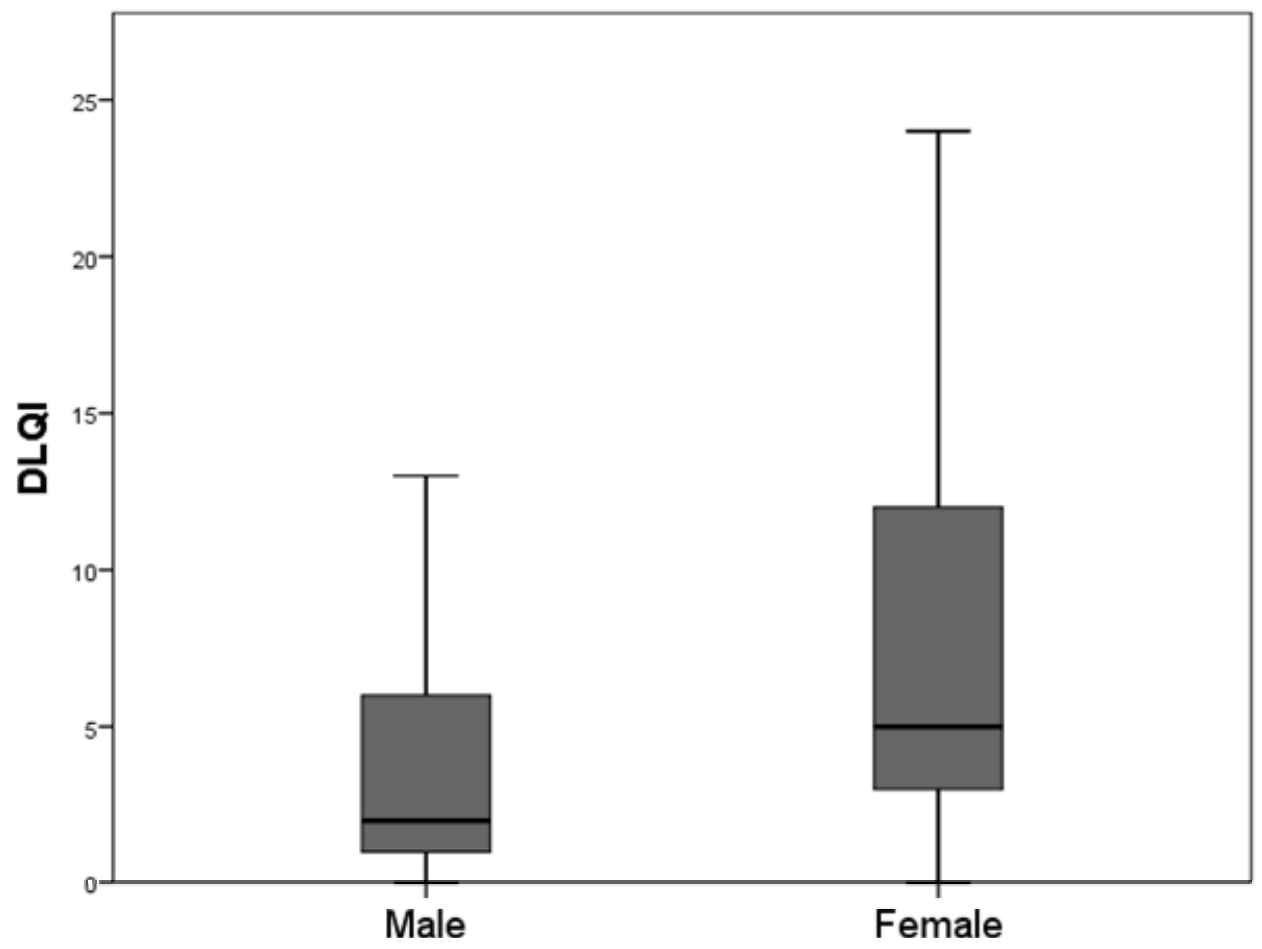

Figure 2. DQLI scores according to gender. 


\section{DISCUSSION}

Chemotherapy and EGFR inhibitor related skin toxicities in cancer patients are a relatively frequent occurrence, with an important impact on patient quality of life which can have significant implications from a therapeutic point of view. About $50 \%$ of newly diagnosed cancer patients will develop a treatable skin condition during or after their oncologic treatment [9]. A particularly interesting characteristic of these adverse reactions is the association between the severity of the skin toxicities and a favorable response to therapy. This paradox means that patients with the most severe manifestations, including grade III and IV CTCAE toxicity, requiring systemic therapy for their skin conditions, are likely to benefit the most from their oncologic regimen.

In our study we analyzed the impact of skin toxicity on patient's quality of life using a standard dedicated questionnaire - the DLQI. We found that moderate and severe adverse reactions have a significantly greater impact on patients' social lives than mild or moderate skin toxicities. Furthermore, these reactions appear to alter women's quality of life significantly more than men's QOL $(\mathrm{p}=$ 0.038). To our knowledge this is the first study suggesting that gender may play an important role in the perceived impact of cancer therapy-related skin toxicity on patients' quality of life.

A secondary end point was the association between the severity of skin toxicities in these cancer patients and the response to oncological treatment, based on Response Evaluation Criteria In Solid Tumors (RECIST). According to literature data, the patients who developed grade 3 or 4 CTCAE skin adverse reactions had a better outcome and cutaneous side effects seem to become a sign of drug activity and a marker of predictive response and survival to oncologic treatment $[10,11]$. The results from our study were consistent with previously reported data, with response at 3 months signifycantly associated with the severity of skin toxicity.

Of course, our study has some limitations regarding the facts that it is a single center trial, with a relatively small number of patients. The cohort is heterogeneous, it includes patients that received both chemotherapy (taxanes) and targeted therapy (i.e. EGFR inhibitors).

Because of the limited number of patients included, we could not conduct extensive subgroup analysis; however we explored some potential confounders that might influence our results. The most important potential source of bias was the heterogeneity of treatment regimens, including both taxan-based and targeted therapy - our analysis showed there was no significant difference in the severity of cutaneous toxicity or the impact on patients's quality of life between these subgroups.

Because of the significant increase in the number of patients receiving cancer treatment with these new oncologic drugs, it is important to understand the impact of such adverse reactions on the patients' quality of life. The evaluation of the relationship between DLQI and dermatological toxicity caused by EGFR inhibitors was also recently analysed in the ObservEr study. This was an observational multicentric prospective trial that evaluated the efficacy of cetuximab (EGFRI) in first line treatment of stage IV colorectal patients, but it also studied the severity of skin reactions to this therapy and the impact of patients' quality of life, using the DLQI score. Good management of cutaneous adverse effects did not affect compliance to treatment, patients maintained a good QoL and the investigators observed a positive association between skin toxicity and response to treatment [12], findings which are similar to those of our own study.

To our knowledge, ours is the first prospective study of oncologic patients with skin toxicities in Romania. Our findings are generally consistent with data previously cited in the literature, with a novel element related to the potential relationship between patient gender and perceived deterioration of QOL. Further studies are required to investigate this particular relationship and potential causal mechanisms in order to better understand and manage the side effects of cancer therapy.

Conflict of interest: The authors declare that there are not conflicts of interest.

Introducere. Toxicitatea cutanată la pacienții cu tratament activ oncologic a devenit un marker de activitate in vivo al medicamentelor, având însă un impact important asupra calității vieții bolnavilor. Aproximativ jumătate dintre pacienți dezvoltă în cursul tratamentului reacții adverse cutanate, de aceea diagnosticul rapid şi managementul corect al acestora influențează complianța bolnavilor la tratament şi calitatea vieții acestora. 
Materiale şi metode. Am efectuat un studiu prospectiv al pacienților oncologici din clinica noastră care au dezvoltat reacții adverse cutanate la tratamentul oncologic. Acestea au fost evaluate conform scalei CTCAE (v4.0) iar impactul asupra calității vieții pacienților a fost măsurat folosind chestionarul DLQI. Am cercetat posibila corelație dintre severitatea reacțiilor cutanate şi răspunsul la tratamentul oncologic (conform RECIST).

Rezultate. In studiu au fost înrolați 52 pacienți. Bolnavii care au prezentat reacții adverse cutanate grade 3 şi 4 au avut un scor DLQI semnificativ mai mare, cu impact puternic asupra calității vieții, dar cu răspuns clinic mai bun la tratamentul oncologic. Astfel, bolnavii care au dezvoltat toxicitate cutanată moderată/severă au avut o rată de răspuns complet sau parțial la tratament superioară celor cu reacții adverse cutanate uşoare (16/33 vs. 3/19, $p=0.035)$. Femeile au avut un scor DLQI semnificativ mai mare față de bărbații diagnosticați cu acelaşi grad de severitate a toxicității cutanate, cu scăderea calității vieții personale şi profesionale (7.28 \pm 7 vs. $3.7 \pm 3.6, p=0.038)$.

Concluzii. Toxicitatea cutanată este un efect advers des întâlnit la pacienții aflați în tratament activ oncologic, gradul ei de severitate fiind un marker precoce de apreciere a răspunsului la tratament.

Correspondence to: Maria Alexandra Barbu, M.D, Medical Oncology Department,

Elias University Emergency Hospital, 17 Mărăşti Bvd, Bucharest, Romania,

Telephone: +40727824017

E-mail: m.barbu86@gmail.com

\section{REFERENCES}

1. M.E. LACOUTURE. Importance of dermatological care for patients with cancer, The Asco Post, 2012, http://www. ascopost.com/issues/september-15-2012/importance-of-dermatologic-care-for-patients-with-cancer/ [accessed December 2017].

2. CHMIELOWSKI B., TERRITO M. Cutaneous Complications in: Manual of clinical oncology, Wolters Kluwer, Philadelphia, 2017: 29.

3. GULATTE M. Symptom Management in: Clinical guide to antineoplastic therapy - a chemotherapy handbook, Oncology Nursing Society, Pittsburgh, Pennsylvania, 2014:13.

4. BOERS-DOETS C.B. How to measure the impact of dermatologic and mucosal adverse events on symptom burden and quality of life, The Asco Post, 2013, http://www.ascopost.com/issues/december-15-2013/how-to-measure-the-impact-of-dermatologicand-mucosal-adverse-events-on-symptom-burden-and-quality-oflife/?utm_source=TrendMD\&utm_medium=cpc\&utm_campaign=The_ASCO_Post_TrendMD_0 [accessed December 2017].

5. NATIONAL CANCER INSTITUTTE - DIVISION OF CANCER TREATMENT AND DIAGNOSIS, Cancer therapy evaluation program, https:/ctep.cancer.gov/protocoldevelopment/electronic_applications/ctc.htm [accessed December 2017].

6. FINLAY AY, KHAN GK. Dermatology Life Quality Index (DLQI) - a simple practical measure for routine clinical use. Clinical and Experimental Dermatology. 1994; 19(3):201-6.

7. DEPARTMENT OF DERMATOLOGY, QUALITY OF LIFE QUESTIONNAIRES, CARDIFF UNIVERSITY, http://sites.cardiff. ac.uk/dermatology/quality-of-life/dermatology-quality-of-life-index-dlqi/ [accessed December 2017].

8. HOFHEINZ RD, DEPLANQUE G, KOMATSU Y, KOBAYASHI Y, OCVIRK J, RACCA P et al. Recommendations for the prophylactic management of skin reactions induced by epidermal growth factor receptor inhbitors in patients with solid tumors, The Oncologist. 2016; 21:1-9.

9. LACOUTURE ME. Skin conditions can have severe impact in cancer patients, Oncology, 2011, http://www.practiceupdate.com/ content/skin-conditions-can-have-severe-impact-in-cancer-patients/13155/62?trendmd-shared=1 [accessed December 2017].

10. PEREZ-SOLER R, CHACHOUA A, HAMMOND LA, ROWINSKY EK, HUBERMAN M, KARP D, et al. Determinants of tumor response and survival with erlotinib in patients with non small cell lung cancer, J Clin Oncol. 2004; 22(16):3238-47.

11. VAN CUTSEM E, TEIPAR S, VANBECKEVOORT D, PEETERS M, HUMBLET Y, GELDERBLOM H et al. Intrapatient cetuximab dose escalation in metastatic colorectal cancer according to the grade of early skin reactions: the randomized EVEREST study, J Clin Oncol. 2012; 30(23):2861-8.

12. PINTO C, DI FABIO F, ROSATI G, LOLLI IR, RUGGERI EM, CIUFFREDA L, et al. Observational study on quality of life, safety and effectiveness of first line cetuximab plus chemotherapy in KRAS wild type metastatic colorectal cancer patients: the Observ Er Study. Cancer Med. 2016; 5(11):3272-81. 